\title{
Empowering and Resisting in a Sharing Economy: Two Sides of the Same Coin
}

Gicelda Julia Dal Bó ${ }^{1}$

Maira Petrini ${ }^{1}$

${ }^{1}$ Pontifícia Universidade Católica do Rio Grande do Sul, Escola de Negócios, Porto Alegre, RS, Brazil

Received 18 November 2018. This paper was with the authors for four revisions. Accepted 25 October 2019. First published online 27 November 2019.

Minelle E. Silva and an anoynimous contributor served as the associate editors for this article.

Editorial assistant: Luciane Kato Kiwara

Editor-in-chief: Carlo Gabriel Porto Bellini 


\begin{abstract}
Some can regard the sharing economy (SE) as a sustainable economy for allowing innovative (even disruptive) business opportunities and for encouraging new forms of consumption. There are, however, controversies about SE's role in being a commercially-oriented economy taking advantage of regulatory and market failures. Such ambiguous trajectories provide opportunities for research, and one of them brings attention to power's exercise to promote or influence change. This research, a single-case study of Uber, aims to understand the connections between framings to empower and to resist in a SE context. Three two-sided (empower and resist) perspectives - the economic system, the business market, and the sustainable-driven perspectives - and two strengthening actions - searching for legitimacy and fighting and calling for status quo - arise within the SE context analyzed. Empowering framings sounded more convincing compared to resisting ones, and resisting framings highlighted contradictions not expected from SE initiatives. Our findings suggest that SE does have the potential to stimulate a kind of nonreversible sustainable mindset, but this path choice is still unclear.
\end{abstract}

Keywords: sharing economy; sustainable development; empowerment; Uber; narrative framings. 


\section{Introduction}

The sharing economy (SE) is a new economy that combines several business initiatives under a single umbrella. Some are not divergent from conventional models. Organizations inside the old economy headed the phenomenon, such as Zipcar (Eckhardt \& Bardhi, 2015); Car2Go (Firnkorn \& Müller, 2011) or DriveNow (Belk, 2014). There are also models tagged as hybrid businesses. Usually, they are for-profit platforms based on peer-to-peer (P2P) networks models such as Uber and Airbnb (Cohen \& Sundararajan, 2015). Finally, within this umbrella, we may also find actual P2P models. They work without profit intermediaries, such as FreeCycle that swaps goods (Krush, Pennington, Fowler, \& Mittelstaedt, 2015) and OurGoods offering knowledge exchange (Schor, Fitzmaurice, Carfagna, Attwood-Charles, \& Poteat, 2016).

With so many business initiatives under a single umbrella, the SE role in a sustainable economy is taken as controversial and paradoxical (Verboven \& Vanherck, 2016). There are reasons to acclaim SE as sustainable businesses and to strengthen the perception of its ability to reduce environmental impacts (Fremstad, 2017). SE offers innovative (sometimes, disruptive) business opportunities and appeals to ecological awareness as it encourages new forms of consumption (Bonciu \& Bâlgăr, 2016; Heinrichs, 2013). Similarly, SE has to do with anti-consumption movements (Hamari, Sjöklint, \& Ukkonen, 2015). SE's dark side of critical topics calls attention to the negative externalities like the rebound-effect on behavioral and systemic levels as the new economy moves from old to new models (Verboven \& Vanherck, 2016). Also, there is a discussion on one-sided advantages endorsed by regulatory and market failures that weakens relevant social aspects such as labor relations (Malhotra \& Van Alstyne, 2014) and their pathway to a more commercially-oriented economy (Martin, 2016).

Such SE trajectories shed light on its ambiguities as well as provide opportunities to investigate the phenomenon looking forward to finding out how these trajectories are (or are not) talking to each other. Some authors bring attention to power exercise as a means to promote or influence changes (Avelino, 2017; Avelino \& Rotmans, 2011). Aligned with this, Martin (2016) conducted research to identify narrative framings to empower and to resist SE. While his study aimed to identify framings without integrating them, we look forward to fitting together resisting and empowering framings as complementary strengths. The idea is to seek what is shared between the two strengths (resisting and empowering), identifying the different ways that both narratives give meaning to the resources they apply. A set of strengths which affect social actors and their narratives produces power relationships, and it is central to recognize such dynamics (Silva, Carrieri, \& Souza, 2012).

Being so, understanding resistance and empowerment as mutually constitutive interactions, we propose the following research question: How are narrative framings to empower and to resist connected in a SE context? Our goal is to offer further reflections on current discussions in regards to SE's path-splitting view (Geissinger, Laurell, Öberg, \& Sandström, 2019; Heinrichs, 2013; Schor \& Attwood-Charles, 2017). For developing it, we use the narrative framings to empower and to resist (Martin, 2016), seeking to find some relational issue (same coin) between them (two sides). The results take this into account, attempting to see how and which framings




are connected. We expect the SE framework developed herein to contribute both in theoretical and practical ways. By achieving a more comprehensive understanding of what is at stake, we propose there is a reasoning to the narrative framings, from a broader perspective.

The next section describes the empirical and theoretical context of the research.

\section{Theoretical Background: Narrative Framings on Sharing Economy}

Our society keeps tracking the exponential growth of the Sharing Economy (SE) over all types of economic activities, including alternative ones. SE encompasses a variety of models, in complexity and scope, as it combines cutting-edge communication technology and networked communities (Bardhi \& Eckhardt, 2012; Dowling \& Kent, 2015). It can be described as an alternative economy arrangement which shares underused assets and reformulates traditional market behavior, such as renting, lending and swapping (C. S. de Freitas, Petrini, \& Silveira, 2016). Its emergence is associated with the increase of online platforms and the exponential growth of start-ups like Uber and Airbnb (e.g., Avital et al., 2014; Hong \& Vicdan, 2016; Martin, Evans, \& Karvonen, 2018). The SE shares resources in billions of dollars (Martin, 2016) and estimates predict a global leap from $\$ 15 b$ in 2015 to $\$ 335 b$ in 2025 (Price Waterhouse, 2015).

Still, its purpose stands on fostering collaborative ways in the opposite direction from business approaches that are no longer tenable (e.g., Heylighen, 2017; Sprague, 2015). Such a particular point of view makes it possible to think on SE with the notion of a sustainable development meant to be better than capitalism (R. de C. M. Freitas, Nélsis, \& Nunes, 2012). That is, SE proposes to meet human needs through a path as distinct as that oriented to the market (e.g., Benkler, 2006; Martin \& Upham, 2016; Rifkin, 2014). Therefore, there are those who understand that SE adopts disruptive practices evoking market intelligence focused on sustainable development (Heinrichs, 2013). Although one may see sustainable development as inherent to SE (Botsman \& Rogers, 2011), it seems to not directly imply that it is moving away from this idea of market orientation.

To the contrary, SE has been seen as "constructing the right kinds of markets, as opposed to getting the right policies enacted" (Konefal, 2013, p. 343) aligned with the understanding of a reframed SE as an economic opportunity (Martin, 2016). A softened view on sustainable development makes it possible to show SE that aims to "reconcile economic growth with human development and environmental quality” (R. de C. M. Freitas et al., 2012, p. 48). Of course, coming to terms with this reconciled view does not necessarily lead to harmony, nor avoid harsh interests revealing internal (Boyd \& Kietzmann, 2014) or external impacts (Heylighen, 2017) either negative or positive. Instead of reshaped pathway to sustainable development (Heinrichs, 2013), one can doubt if it is an "economy that benefits everyone" (Morozov, 2013, p. 3) and question whether SE effectively grants better quality of life. However, this does not mean it is not going to take place. There appears to be potential to, intentionally, promote structural changes for sustainable development (Benford \& Snow, 2000; Smith \& Raven, 2012). 


\section{SE arguments (still) unlikely to agree}

The field of studies on SE seems to lead the discussion to the controversies generated by the notion of neoliberalism. Studies reveal disagreement in aspects ranging from relationships with the market, government, workers, consumers (users), to sustainability and environmental issues (Murillo, Buckland, \& Val, 2017). The assumption taken for granted, as far as digital platforms are concerned, is that there should be minimum state interference in the market, i.e., the neoliberal idea of the less regulated the market, the wider the benefits to shareholders (McKee, 2017). This is inherent in the way corporations such as Uber are replacing current jobs with precarious gigs that lack protection and legal benefits (Zwick, 2018). It turns out, advocate McKee (2017), that such platforms ended up being the result of self-regulated rules adopted by SE's new models and state regulatory laws. The logic of an inclusive and empowering job is still not clear and brings instability and tension: the most influential and powerful SE firms are private and profit-driven but still not as taxed and regulated as the traditional ones (Laurell \& Sandström, 2017). There is no doubt that Uber (and similar apps) expanded its competitive advantage over the taxi industry using information technology to identify gaps in law enforcement (Zwick, 2018). SE seems to operate between the voids of law and societal vulnerability (Dreyer, Lüdeke-Freund, Hamann, \& Faccer, 2017).

Technological innovation becomes the trigger through which digital platforms begin to change the world of work as it was previously known (Donini, Forlivesi, Rota, \& Tullini, 2017). To check on how far this revolutionary innovation will go, a theoretical body of still inconclusive studies and conflicting views is on its way (Fabo, Karanovic, \& Dukova, 2017). Only as such revolutions continue can one assess whether trends will prove themselves as being a drive to "undermine labor laws and other regulations, transfer industry risk to the individual driver, and lower industry wage and labor standards" (Zwick, 2018, p. 687). It turns out that the relationship between corporation, worker (partner) and customer (user) has become blurred and has given rise to specific problems that regulation has been unable to keep up with as SE advances (Griffith, van Esch, \& Trittenbach, 2018).

The generation of damages or costs arising from the relationship between the drivers and the forprofit platforms (like Uber) shows the way of how over-exploiting work also has side effects (Heylighen, 2017). Over time it seems that digital platform exchanges become less disruptive and more similar to standard services, meaning positive and negative implications for sustainability (Schor \& Attwood-Charles, 2017). Recent studies have shown more or less sustainability depending on how a corporation chooses to use available resources to strengthen the dominant market logic or to reshape it (e.g., Bohnsack, Pinkse, \& Kolk, 2014; De Stefano, 2015; Hockerts \& Wüstenhagen, 2010; Sosna, Trevinyo-Rodríguez, \& Velamuri, 2010).

\section{Exploring previous research on SE's narrative framings}

Martin's research (2016) explores SE critical narrative paths, supporting his research on transitions and narrative framing literature. Narrative framing is a process through which actors'

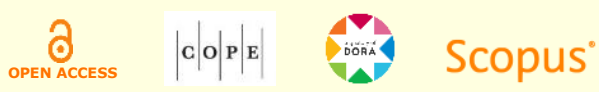


narratives are considered intentional, appealing and seeking to mobilize a consensus and collective action around a given issue (Benford \& Snow, 2000; Czarniawska, 2010). At the core of transitions studies is the analysis of how to exercise power, be it as a way of regulating available resources or as a capacity of triggering them as to promote sustainable changes in social systems (Avelino \& Rotmans, 2009, 2011). To understand SE transitions, Martin (2016) applied a multilevel perspective (MLP) framework (Geels, 2004, 2010; Rip \& Kemp, 1998) which analyzes the interplay between two socio-technical systems: the regime (relatively stable structures) and the niche (revolutionary innovation). Working on these assumptions, Martin (2016) finds six narrative framings, three to empower, and three to resist SE. His analysis shows that regardless of SE's socio-technical level, actors make use of conflicting structures.

This means that the same narrative framing could be employed at a micro-level (niche level) or at an intermediary level (regime level). Some are more extensively employed by regime actors. Such framings work on the idea of SE as typical commercial businesses and characterize it as a new economic opportunity (i.e., empowering the SE) or as taking rights or privileges away due to unregulated marketplaces (i.e., resisting the SE). Likewise, the niche actors extensively use narrative framings providing the SE with the right attributes for sustainable consumption operating as a pathway to a decentralized, equitable and sustainable economy (i.e., empowering the SE). Niche actor narratives also deal with resisting the SE. Such framings criticize the SE for reinforcing the neoliberal paradigm and for being somewhat incoherent as far as effective innovation is concerned (details in Martin, 2016, p. 158). It is worth mentioning that our study chooses not to distinguish between the regime and niche narratives, as Martin (2016) did, but place them as they concern one another.

The framings to empower are: (a) an economic opportunity; (b) a more sustainable form of consumption; and (c) a pathway to a decentralized, equitable, and sustainable economy. These framings outline, for example, the idea that SE encourages economic development by offering new income practices for both individual and organizational entrepreneurship. Besides, they place SE as a disruptive business in that such a business models prioritize access over ownership and address social (and environmental) emergent issues. The framings to resist are: (a) creating unregulated marketplaces; (b) reinforcing the neoliberal paradigm; and (c) an incoherent field of innovation. These narrative framings emphasize lack of transparency in applicable rules as well as lack of regulations. Such narratives drive a perception that such non-regulated businesses characterize threats for both the market and the consumers. Under an appearance of sustainability, there seems to lie some inconsistencies such as in place of transparency, there is corporate co-option, for example by stacking the board of directors or avoiding independent auditors; instead of entrepreneurship empowerment, there is labor-related precariousness and randomness. Another aspect is that only those who own - assets or resources - can effectively share them. Narrative framings to resist show that SE does not share, but use in the sense that meets private (not collective) interests.

We approached such dynamics as pertaining to power relations where community and stakeholders stand for enablers of change (Avelino, 2011). In this sense, actors exercise power through their ability to mobilize resources either for the common good or self-interest to achieve

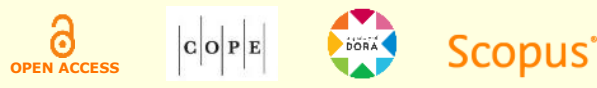


a particular goal (Avelino \& Rotmans, 2009). Actors are embedded with available resources for mobilizing information, ideas, shareholders, members, infrastructure, physical space, time, funds, etc. (Avelino \& Rotmans, 2009, 2011). The relationship among and with the local community are vital to legitimizing SE activities (Gomes, 2005).

Managing resources to empower and to resist may be a tool to turn the game and change directions. Avelino and Rotmans (2009) suggest that one could be more or less influential depending on the actor's ability or the context. It is necessary to acknowledge the best way to make existing resources as functional and efficient as possible, but also to be aware that the volume (in numbers) of available resources, if compared to the opposite side, counts (Avelino, 2009). Avelino (2009) raised issues on how to be both efficient and functional: (a) recognizing where to find and who owns the appropriate resources, (b) knowing how to mobilize resources, (c) knowing how to pursue the right skills to carry out a strategy (e.g., physical strength, strikes, networking, voting, etc.), and (d) having the will to exercise power. All of them may be complementary to each other or replace one another, and open windows of opportunity to pressure either for change or keep things as they are and gives support to what we identified as strengthening actions presented in the next sections.

\section{Method}

We applied a qualitative and exploratory method to a single case study (Langley \& Abdallah, 2011), that of Uber. Uber grew fast and, by the end of 2019, expanded into more than 700 cities spread out over 63 countries, with 91 million monthly active platform consumers and 3.9 million drivers (Uber, n.d.). In Brazil, Uber started in the same period as the Soccer World Cup held in 2014. Currently, Uber has reached around 600,000 partner drivers and 22 million active platform consumers in more than 100 Brazilian cities (Uber, 2019). This study followed an online trajectory covering Uber's arrival in the first eleven Brazilian cities over twenty-eight months: Belo Horizonte, Brasília, Campinas, Curitiba, Fortaleza, Goiânia, Porto Alegre, Recife, Rio de Janeiro, Salvador, and São Paulo (in alphabetical order).

We considered a two-phase research design supported by using the NVIVO application: online data gathering followed by a short complimentary sample of interviews. We started (first phase) by classifying narratives within the six previous framings as proposed by Martin (2016). As we move forward in the research, we begin to identify some common strand, not discussed in the previous study (Martin, 2016), wherein framings, to empower or to resist, start to connect as the two sides of the coin, with both looking forward to answering some relationship or proportion of a greater whole from a particular standpoint. Going further we also observe a mode used to strengthen the position of one side facing the other.

The online data covered newspaper articles, columns, blogs, infographics, reports, and all related news tackling Uber issues. We grouped them into general, specialized, and institutional online sources (Figure 1). 




Figure 1. Online information

The first group represents Uber's first eleven cities. The second and third groups comprise specialized media. The CONJUR (www.conjur.com, retrieved August 24, 2016) and MIGALHAS (www.migalhas.com.br) websites were designed to provide access to legal issues, and along with WRI Brazil (http://www.wricidades.org/, a branch of WRI Ross Centre for Sustainable Cities), an urban mobility sustainable-driven $\mathrm{ONG}$, make up the specialized media. Two websites of federal institutions, Conselho Administrativo de Defesa Econômica (CADE, www.cade.gov.br), a council responsible for the economic defense, and Ministério Público Federal (MPF, www.mpf.mp.br, retrieved August 24, 2016), the national prosecution service acting whenever diffuse, collective and/or homogeneous individual interests of Brazilian citizens are at stake make up the institutional media.

The material collected online ensured the adequacy and quality of the data to support this study. At the time we were working in the field, the news, information, and discussions about Uber's operations in Brazil were easily accessible. We gathered 1,014 items in a preliminary reading and selected a total of 793 for in-depth analysis, mostly disposing of those with identical or repeated information in two or more media. Since the associated online data included such a great extent of items, the approach adopted consisted of a gathering and analysis iterative process focusing on the six framings. After we finished this phase, we conducted interviews to catch the lived experiences of people who have, in some way, observed Uber's approach.

The respondents were meant to endorse the results from the first phase, but also to eventually identify some other aspects not raised before. Three groups were interviewed (Figure 2): the Community group involved two partner drivers (DRIV1 and DRIV2) and two users (USER1 and USER2). We grouped as Practitioner one respondent from WRI (NGO), a non-governmental organization dedicated to promoting sustainable cities, and one from a private company (ICT), a taxicab and riding application provider. It is worth mentioning that we made some attempts to interview Uber's executive personnel, but they failed. Lastly, the third group has two respondents

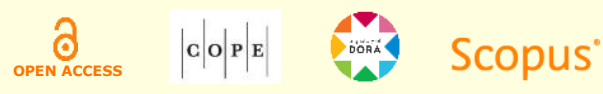


(PCTC1 and PCTC2) from a public transport company, and one (CPA) from the local consumer rights protection agency.

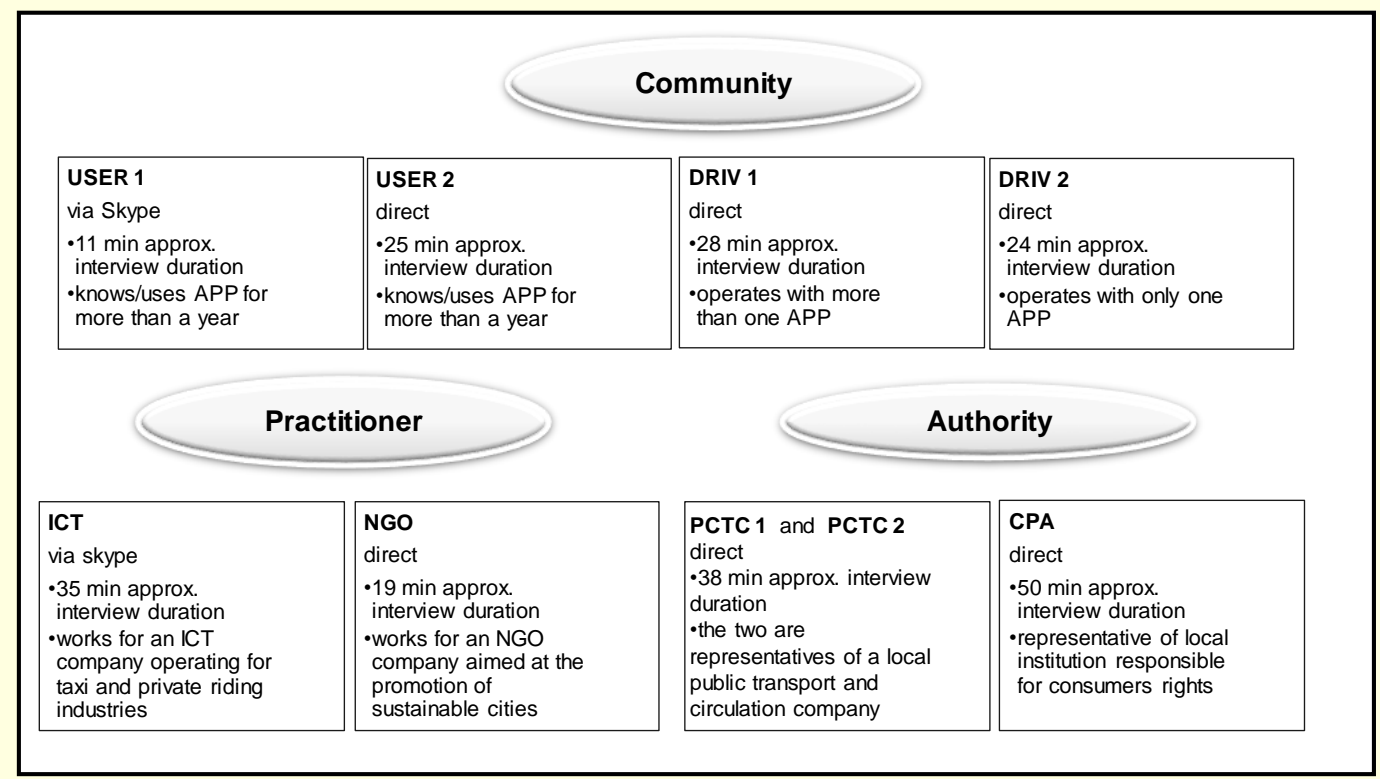

Figure 2. Interviews

The online material, as well as the interviews, follow in the same direction, and the results obtained are reported in the following sections.

\section{SE in Perspective}

By the time we started field research, using the framings proposed in Martin's study (Martin, 2016), we observed that the two sides of the coin (to empower and to resist) somehow sought to answer some relationship or proportion of a greater whole from a particular standpoint. We acknowledged three perspectives, each characterizes a common thread that binds together these two opposing sides to the SE. They are the economic system, the business market, and the sustainable-driven perspectives. Each of them stands for a coin and the framings to empower and to resist stand for the two sides of a coin. Further, we brought up two strengthening actions steps either to get approval from or to contest this new way of providing services in urban mobility.

The empowering strengthening action, labeled as searching for legitimacy, is related to a way to achieve commitment from the community to this new service provided by Uber. Narratives marked as searching for legitimacy look forward to emphasizing how reasonable and justified (as common sense) their actions and initiatives appear to be. The resisting strengthening action, fighting and calling for status quo, refers to a way to bring non-favorable impressions. Narratives of fighting and calling for status quo intend to avoid the new and show initiatives that make use of robust mechanisms (including use of force) to preserve status quo and put an end to unfair 
competition. We take some excerpts of data collected to illustrate narrative framings and give foundation to the framework proposed within the next sections (Figure 3).

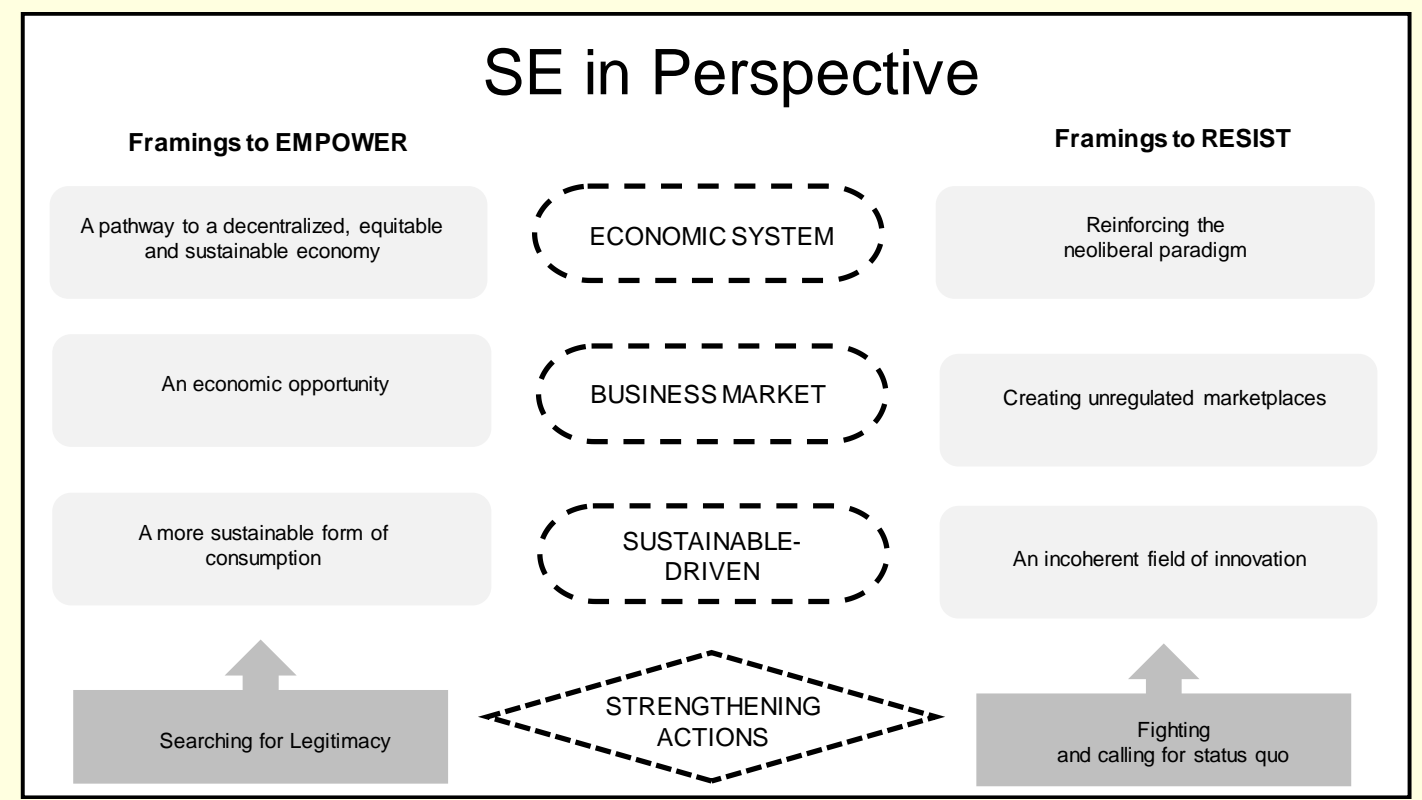

Figure 3. SE in perspective: A theoretical framework

We begin by presenting the coins, the three perspectives each with their respective sides, the narrative framings to empower and to resist. And then, in sequence, we show the peculiarities of the two strengthening actions.

\section{Perspectives: The common thread behind the narrative framings}

The three perspectives with their two-sided framings to empower and to resist are presented in the next sections.

\section{An economic system perspective}

The economic system perspective points out a general discussion on whether SE's business features are or are not capable of changing the contemporary neoliberal economy. Its two sides are a pathway to a decentralized, equitable and sustainable, economy and reinforcing the neoliberal paradigm.

Empowering SE in an economic system perspective: A pathway to a decentralized, equitable and sustainable, economy

We identified two elements to support this framing: 
1. An economy based on values of democracy, freedom, and justice. This framing includes economic features based on democratic values. Provided the decentralization of power structures, the role of society (its welfares) increases at the heart of the discussions: "this is not a government issue. It is society's debate" (Government representative - "Decisão sobre regulamentação", 2016, our translation). Everyone has the right to choose and to question their surroundings, as well as what is (or is not) driving the community actors. Within such new structures of power, the challenge seems to find solutions that do not "hinder innovation or deprive the user of its benefits" (International correspondent - Ninio, 2015, our translation). It is no longer possible to leave aside (or deny) the strength and space occupied by technological innovation. Under values of democracy, freedom, and justice, new shapes continuously emerge in society to afford both individual and collective welfare.

2. The use of digital technology. As far as technology is concerned, there "[is] no going back [as] technology won't stop" (USER2). Nowadays, "[it is] technology that will link the world" (DRIV1). The economic system has changed, and technology features a wire connecting people with the digital world in such a way that "instead of fighting against new technologies, [one must] see how [to] adapt and take advantage of this evolution" (Practitioner - Hofmeister, 2016, our translation). Now is time for high investment and unexpected (until a short time ago) partnerships. Technology and communication companies are reliable, desirable, and highly rated partners for social media companies, vehicle assemblers, and several other economic activities. Integration is their strategy; otherwise, in a short time, they may lose attractiveness. They see it as "[the] opportunity to learn [about] various market sectors" (Technology Company Manager “Apple investe US\$1 bilhão", 2016, our translation). Such alliances are potentially changing the economic system. Additionally, if it requires a given technology and there is no (and it is not expected a) way out, the economic system should define who will pay the account (and in which conditions) in this new decentralized, equitable and sustainable, economy: "the roads should be built [and] someone has to pay the bill" (NGO).

\section{Resisting SE in an economic system perspective: Reinforcing the neoliberal paradigm}

We identified two elements to support this framing:

1. Increasing precariousness and randomness regarding labor issues. At the top of the list are narrative framings about how random and precarious labor issues are. The very evolution of ICT (Information and Communication Technologies) is leading to new business models (like SE businesses). In such new economic systems, "companies began to see themselves as thin slices ... between consumers on the one hand and their workforces on the other" ("Tendência teve início na década", 2015, our translation). It makes a kind of "mutation" happen through which "all these technologies are burying jobs and creating new ones" (Columnist - Ming, 2016, our translation). In this economic system in transformation, individuals become responsible for risks and costs until they are taken over by employers. See, for example, a comment from Uber about Uber: "it is not the company that hires drivers, but the drivers who hire the company to use the application" (Domingos, 2016, our translation). No doubt, the driver chooses this or that

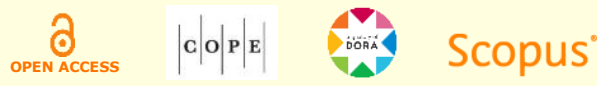


application to use. But their freedom and equity sound like a fallacy as they argue: "the driver, when connecting the application, has but only one option [which is] strictly follow the rigid rules established in a rough way by the apps algorithm created and managed by the company" (Legal expert - Chaves, 2016, our translation).

It is not clear who (or what) gives orders and how this relationship evolves. In general, Uber represents an alternative to conventional business models. However, digital relationships with customers and stakeholders begin to show a fresh face, meaning that more and more connections will be in virtual modes. The leading voice comes from the chief algorithm (an expression used in the market to explain who or what is in charge): "Uber driver does not have an individual [but] an algorithm that gives orders" (ICT). This peculiar situation makes someone reasoning "[if] rapport is not physical [the building of a] trust relationship is not with the driver, do you understand?" (CPA). Nor it is with the user. [Not knowing who is in charge] leads to unclear levels of responsibility. There will be some weighing scale, or is this it: a way to the intensification of precariousness and randomness labor issues?

2. Corporate co-optation. Corporate co-optation is the process where the economic (and political) power comes into play. Under technology-driven business standards SE businesses show signs of co-option whenever they look forward to "increasing labor market flexibility by eroding workers' rights; commercializing aspects of life that were previously beyond the reach of the market; and, creating paradoxical social impacts, economically empowering some individuals whilst reinforcing structural inequalities" (Martin, 2016, p. 157). We can understand co-option to adopt some idea or policy for one's use, just like Uber seems to do in both public and private fields. In the market, Uber acts as if it is in a war in "a crazy climb to leave players without resources” (International columnist - Sorkin, 2016, our translation). Such a way of doing business brings "a long list of competitors, large and small companies, who say [if Uber can act in a controversial and doubt way, the competitors considers they] can do that too" (International columnist - Sorkin, 2016, our translation). Within the public arena, Uber seems to run "a political campaign [wherein the company is] the main candidate and [the opposition, the] taxi cartels" (CEO Uber - Aguilhar, 2014, our translation).

In this way, Uber adopts a political platform to protect what it considers suitable to its SE business model by promoting a "[public] debate on what sort of market rules [calling for democracy] people expect" (Uber manager - Cazarré, 2015, our translation). Perhaps, this explains Uber's positioning on each occasion the company starts a new city operation. Instead of being concerned with approaching municipal authorities before entering, looking forward to an agreement on how to manage and regulate its activities, the company would slightly enter. Taking advantage of mass media, Uber keeps declaring it "remains open to debate with the public administration [almost stressing it should be] an affirmative ruling [i.e., involving the least possible intervention in a way that] allows us [Uber] to [make] use of technology for the welfare of people and their town" (Uber Blog - Fabio, 2016, our translation). This defiance has caused clashes; it placed Uber and its partners (the drivers) as agents of underground activity. While remaining outside the law, they were clandestine (public town representative - "Uber será tratado como transporte", 2015, our translation).

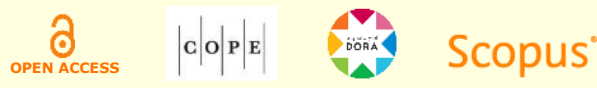


In the opposite direction to that of a decentralized economy, corporate co-option seeks to manage its interests, be it in private or in a public scope. For decision guidance, in place of sitting at the table with its competitors or with the civil authorities, Uber seems to act as if it is on a campaign trail in which the goal is to win no matter what. The resistance side of the economic system perspective showed a path where approaches and strategies persistently remain unchanged and somewhat follow a neoliberalist track. In opposition to what the SE proposes to offer - a decentralized, equitable and sustainable, economy -, it chooses to reinforce the neoliberal paradigm.

\section{A business market perspective}

The business market perspective highlights the pros and cons of the new SE models and touches on issues such as if being disruptive could break with the status quo in such a way to reshape sustainable development. The related framings are an economic opportunity and creating unregulated marketplaces.

\section{Empowering SE in a business market perspective: An economic opportunity}

Four elements support this framing:

1. A primarily economic view of sustainability. Uber is a "company that owns an application capable of managing rides in large urban centers" (Capelas, 2014, our translation). In a short time, it has "crossed the threshold of a very first-class club [the ones whose wealth is estimated as] billionaire companies" (International columnist - Saitto \& Stone, 2014, our translation). However, it presents as a local company. Every new city that appears on Uber's blog list as \#on (meaning its App is available in that place) receives a similar approach. Uber acts like an old acquaintance, aware of the typical way of doing things, living and thinking of that city and their people. A way to greet the city that reminds Uber's way of being, for example, "[Belo Horizonte] is a place of outstanding flavors, and breath-taking views [and their people are] hospitable, traditional and at the same time innovative" (Michele, 2014). Accepting cash payment is another illustration for this local approach. Despite breaking its own rules, the company decided to offer cash fees as an option. It worked; as informed in a note "the number of people increased $90 \%$ [talking about those northeast region cities with Uber app available] since we [Uber] started accepting cash" ("Uber começa a aceitar pagamento", 2016). That is a business market strategy that can be associated with a search of adequacy and compliance with the economic side of sustainability.

2. Changes in behavior patterns. Some new alternative behaviors may arise to deal with circumstances and answer pressure. The industry most affected by the emergence of Uber and similar applications is the taxi service. The situation exposed what they could no longer meet, i.e., "[it disclosed that] the needs of the user ... is not appropriately served by [taxis]" (Bernardes \& Alves, 2015, our translation). With competition, users/customers no longer support things accepted before for taxicab service. Due to the lack of options, it was not a good service because

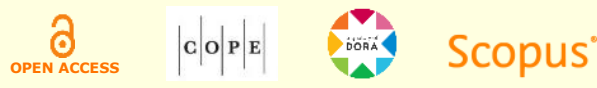


"[the service is] inadequate, uncomfortable, [the car is] poorly preserved [and the whole system allows] law-breaking [advantages] such as renting, reassigning and trading licenses [alongside] even violations against passengers" (Bernardes \& Alves, 2015, our translation). Quality becomes a requirement to be fulfilled, and the passenger (now user) has the right to claim for it "[as] each person has [its own] motivation ... to select [the transport] that meets [his/her] needs [and pinpoint what is] best and reaches [his/her] pocket" ("Saiba quanto custa", 2016, our translation).

Such a change in user behavior may be associated with the poor quality of the services, until then, provided by taxi drivers. To the same extent, it is reasonable to expect a qualitative change of mind from policymakers and public administrators. The complaint is that they should leave the commonplace of "if [the new business activity] does not fit strict interpretation of the law [it should be put aside because] it is against the law or [bounded into] ways to adapt [to formal rules]" (Policymaker - Agostini, 2015, our translation). Both public (policymakers and administrators) and private (competition) fields are noticing that innovative business, like Uber and other SE activities, are not well-matched with protective attitudes of business markets; on the contrary, to change behavior patterns requires exploring new principles.

3. New working and income-generating relationships. Uber comes with "[a] new way of doing business [and] judging by its disclosure power [spreading out] new ideas around the world [it is also a kind of] disruption in the market [in the way] we know it" (Diógenes \& Thomé, 2016, our translation). Unconventional working relationships come up under the argument that "the constrictions of a working day [likewise being present] is no longer of significance to [measure] production efficiency" (Legal expert - Chaves, 2016, our translation). In the sense that technology made this control diffuse (people are connected wherever and whenever they are), making it difficult to measure the relationship of subordination if not in a collective way. Technological accessibility and (almost) instantaneous profitable results are making possible new working and income-generating relationships. With such an "economic crunch [in global level], people lean towards bringing more positive solutions to everyday problems" (Moraes, 2016, our translation). Nothing is better and empowering than to have at hand such economically attractive new ways of income-generation opening space for entrepreneurship.

4. Entrepreneurship. Some key benefits pointed out by those who choose to work with this new business model: network convenience (visibility for the user and for the partner driver), autonomy (a way of self-ruling making it possible to manage when, how often and how to work), and security (if compared with the conventional taxicab model). The individuals who become partners with the company emphasize the freedom and the speed with which they can start their own business. Partner drivers follow Uber's positioning are concerned that "[formal] directives for the use of applications like Uber [do] not end in established rules that limits [their] selfdetermination [as] entrepreneurs" (Galdino, 2015, our translation). They privileged this business model, as you can notice in this narrative: "I bought this car and here [working with Uber] I can make some extra money [that] help to pay [the car] financing [and considering that] the economic crisis is aggressive ... I can work any period I am available" (Uber driver - L. Rodrigues, 2016, our translation). As entrepreneurs who are gratified with the economic progress this business model has made them, the drivers are aligned with Uber's approach to the community: "work the hours

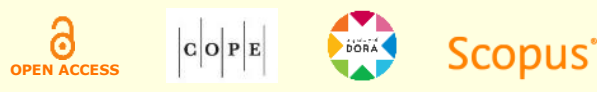


you want; earn what you need; you can start and stop at the time you want; with Uber, you're the boss" (Uber, 2016, our translation).

\section{Resisting SE in a business market perspective: Creating unregulated marketplaces}

We identified two elements to support this framing

1. Establishment of non-legal, black or grey markets. By the establishment of non-legal, black or grey markets, we refer to those operating aside from conventional rules so as to get benefits not feasible otherwise. That is, the SE market may run better between the gaps where regulations are not clear enough or do not exist. Uber has kept its operations even with the stigma of underground activity as far as policymakers and public administrators are concerned. The local governments were set aside while Uber used mass media to seek the support of public opinion whenever the rules (partially or totally) are not welcomed or suitable for its business interests. Despite the company efforts to do the right thing, policymakers are making mistakes that can lead to a large non-legal, black or grey market. The company has requested mutual efforts, but stated that it should be "in line with the thought [of how] service ruling [have to be]" (Uber manager - Leite, 2016, our translation). Uber warned, "imposing limits on the company's activity [will lead to] undesirable [effects] for the city [and it will] stimulate [a kind of] underground market" (Uber manager - Bergamim, 2015, our translation). The narratives lead to the idea that this legitimate status of the service (operating between the voids of the law) of the law and not the other way around is comfortable for business.

2. Unfair competition. The unfair competition narrative explores power inequities in the SE business market. Somewhat questionable principles and dubious values, as far as social ethics are concerned, have been raised in Uber's trajectory. Now and then, the company made some antagonistic choices. Awareness that it could only get (a precise) private information in the makebelieve of hiring, the company proceeded unethically by "ordering one hundred cars from the competition [to] get drivers phone numbers and persuade them [to service Uber]". In the end, they admitted "it was too hostile" (International correspondent - Streitfeld, 2014, our translation). In other circumstances, considering its private access to inside information, news came out that one of its executives suggested "launching a defamation campaign against journalists [that insist on] criticizing [the company]" (Gonzaga, 2014, our translation).

If Uber is somehow comfortable with unusual ways of seeking information, on the other hand, they seem quite obstinate when it comes to providing inside information. For example, Uber does not share how many partners are connected to its application as it considers this information "not as important as it seems [because] there are people [talking about drivers] who spend more time a day [on service] and people who spend less". Moreover, they further say the importance concerning numbers is "the average time it takes for a car [its driver] to reach the user" (Uber manager - G. Rodrigues, 2016). Another topic on unfair competition appears when examining if Uber should (or should not) take the risk and the responsibility for partners and users. The questions that come into discussion arise if it is enough to disable the account of those who break

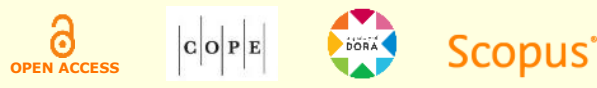


the rules: could it be enough to free a company from liability? In case of lawsuits, would no ties with the company excuse any damage triggered by drivers, users, or other people? There is no final opinion on that.

\section{A sustainable-driven perspective}

Although not necessarily less important, this is the less frequent narrative framing. Through sustainable-driven perspective, we try to see if the narratives read the proposals and practices as indeed oriented towards sustainability. Both sides of the coin here are a more sustainable form of consumption and an incoherent field of innovation.

Empowering SE in a sustainable-driven perspective: A more sustainable form of consumption

The element supporting this framing refers to consumer practices with sustainable potential. The ride-sharing service grew quickly, making possible the emergence of Apps, because "the cities [have] experienced the lack of taxicabs" (Practitioner - "Decisão sobre regulamentação", 2016, our translation). The inside idea is to share (goods or services) at the touch of a button with a massive decision-making base of users/consumers where "[one can measure] success [in such a way that what matters is the] decision of the consumer in a collective approach" (Agostini, 2015, our translation). Such a way of thinking has been unsettling private and public management, and compelling whoever gets touched to seek opportunities and benefits not only within the economical, but also within the social and the environmental aspects of sustainability.

Instead of avoiding innovations or a completely new business model, that is threating the conventional, why not join forces with each other? This is the case of a public initiative for an urban intermodality through which one can choose "leaving home in the morning, picking up a bike with [his/her] single ticket, then [catching] a bus, and [at the end of the day], coming back with Uber" ("Com as novas opções de transporte”, 2016, our translation). It presents, assuming the bicycle belongs to the individual, a composition of ownership, access and sharing where the outcome lean towards improving quality of life where the future seems to be very promising in using technologies for the benefits of cities and people "by qualifying services, by establishing new communication designs, by changing mobility" (Practitioner - WRI Brazil, 2016, our translation).

Although these initiatives are already in motion, the time to ensure they are promoting structural changes and sustainable development has not arrived yet.

\section{Resisting SE in a sustainable-driven perspective: An incoherent field of innovation}

The non-catalyzing profile of transformative change narrative framing refers to discrepancies in the relationships between Uber and its users or partners. It does not seem to be the way to sustainability. We divided this into three distinct aspects: (a) how Uber manages market demand, (b) how Uber makes use of taxicabs' usual practices, and (c) Uber's dubious management of ethical issues. Uber deals with its customers (and this includes drivers and users) in an impersonal




way. The company leaves little space for interactions with drivers. For example, regarding service tariffs, Uber gives an example of a market-oriented way of managing trade operations. The company handles, through an algorithm, the expected market demand. Their drivers report that the tariff goes up or down without prior notice.

Such intervention puts down (or, at least, minimizes) the argument that their partners are free and can self-regulate themselves. It shows limited decision-making, and one may believe more in a ruling, crossing out and controlling operation. The second aspect to point out is regarding Uber consent for its drivers' use of standard and conventional taxicabs practices. Service outsourcing started to be carried out in a very similar configuration of dependence "to the established between license taxicabs holders and taxi drivers" (Diógenes \& Thomé, 2016, our translation). Currently, that means that someone that owns a small car fleet requires payment of part of the earnings of independent app drivers for the use of the vehicle. Instead of reducing the number of cars in urban traffic as expected - use rather than own - such arrangements show limited space for environmental and social sustainability aspects. The third point explores corporate ethics questioning what the limit should be when social values and principles are at stake. The company received intense criticism concerning an agreement with the Saudi Arabia government, giving shreds of evidence of a "tacit approval of the country's policies [where] women are not allowed to drive, and homosexuality is [considered] a crime" (International columnist - "Investimento saudita”, 2016).

We may question; is there a concern with the social welfare and consequently with the social sustainability in such SE businesses? Maybe not. In the short term, sustainability issues seem to have little (or no) direct relationship with Uber practices. Narratives bring an understanding of a gradual change of mind to both individuals and organizations (USER2), which will lead to longterm changes. They will come from such a fruitful period of large companies' mergers and joint ventures that are happening nowadays. Especially the ones among automobile assembling and technology corporations looking forward to meeting consumers demand for less polluting cars "in 30 years we will refer to 2016 as the year of the beginning of [environmental sustainability]" (NGO).

In the next section, we will discuss the two emergent strengthening actions.

\section{Strengthening Actions to Touch Society}

Besides the three perspectives, the field research brought what we describe as actions intended to strengthen a group's position so that they become (or are expected to become) more powerful or more likely to succeed in their goals. The strengthening actions are meant either to get approval from or to contest Uber as a new way of providing services in urban mobility. Within the searching for legitimacy framing, actions lead to getting societal commitment. It calls the community to require the right to use such a service. The activities intended to avoid are framed as fighting and calling for the status quo.

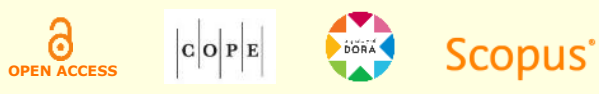




\section{Empowering strengthening action: Searching for legitimacy}

Actions comprising and nurturing active participation from local community embody the essence of this empowering strengthening action. It goes into the community and calls for responsiveness: "with technology we [Uber] can make city a better place [and] mobility a better thing [so, there is no reason for any] structured group protecting corporate interests [to] stop Uber becoming [an option as] a means of transport" (Uber manager - "Audiência para discutir regulamentação", 2016, our translation). Based on this approach, the company requires local communities' participative action as decision-makers. It is very illustrative to observe Uber's approach whenever some vital decision, such as lawmakers voting on local and national rules, may bring difficulties to its operation. The company adopted this way of acting in several circumstances, as in the case of Porto Alegre.

On the very morning of the voting day, they reached out to the local community through newspapers with full-page ads and other media (including its blog and even messaging through the app) as a vehicle to win people to its cause and ask them to make it their purpose too. The message request reached locals with the hashtag \#ficauber (meaning stay Uber). They appeal, "what is at stake is the city that we [Uber] want to build [and] you [each individual or a collective from the local community] can make a difference" (Newspaper publicity - Uber, 2016). The approach directs people to participate "tell [directed to the local community] policymakers you want contemporary regulations [and that they - the rules - should look into] the future [and not] going back [to the past]" (Newspaper publicity - Uber, 2016). They call locals not only to be informed (making it clear what is about to happen) but more than that, to actively collaborate with their claim. Uber oriented and made it easier for the community to do it. They say, "press the link [provided in the message] and send an email straight to the policymaker" (local message content, received by one of the authors via direct email from Uber, personal communication, 2016).

The positive effects noticed is that despite being massively virtual (mostly through social media) their message seemed as if it were direct and personal. Uber made it happen as the company was "progressively evoked, recognized and protected by the people" (PCTC2). No shame at all provided the circumstances; on the contrary, "it seems reasonable for a company that finds a neat gap to try to catch society" (NGO).

\section{Resisting strengthening action: Fighting and calling for the status quo}

This resisting strengthening action functions like disapproval and criticism from taxicabs and the ones who support them (unions, policymakers, and industry corporate organizations). The aim is to uphold a prior market share they considered, until Uber's and similar apps entrance, unbreakable. The public individual transport service had a name and no space for outsider competition. Maybe, for this reason, the way to resist this new SE model and reinforcing paths to keep resisting exposes criticism, judgment and even violent insolences and behavior. It is not new in the history of society as taxicabs and friends act just "like the workers who broke machines




[at the beginning of the industrial revolution]”. The recent past put taxicabs activists and local, regional and national policymakers together to "[try] to block [through] strikes and legal measures [the] developments that are gradually emerging in [private transportation] industry" (Amora, 2014).

Under pressure, these people tried both to get the business out and to bring the company into the taxi system structure. None of them succeeded. With few strategies in hand, passion spoke up with intimidations not only to assets and properties but also to a person's bodily integrity, for example, "pursuing [Uber and other apps] drivers; [making public to Uber drivers] aggressive videos and audios, [sharing through social media networks] information on places not allowed to [Uber] drivers" (Ribeiro, 2016, our translation).

Hostility and clashes have been constant since Uber and similar applications arrived and made life difficult for these traditional organizations. The question is how long this strategy could/should last. Such hostile resisting strengthening action carried more refusal from local communities than an endorsement, which in some way favors the empowering side.

\section{Discussion}

We take framings to empower and to resist as mutually constitutive interactions; i.e., both sides of the coin are potentially able to mobilize resources and intentionally achieve their goals. Being empowered (or resisting) implies managing resources (people, materials or capital) (Avelino \& Rotmans, 2009, 2011) and we found that both sides look forward to making the best use of them. For example, to prevent application' drivers from working (Uber and alike), taxicabs treat the market as a combat zone through strikes, large street assemblies, direct clashes, and even damage to property and individuals. To address this behavior, Uber put into action a combination of its networking capacity and ICT skills to approach and influence local public opinion. Instead of a combat zone, Uber paid attention to local affairs and looked forward to inspiring action, directly or through their partner drivers, by promoting donations of food, clothes, blood, etc. The company also made use of media press and social media (blog, e-mail, Twitter, Facebook, etc.) to manifest its position and to call the community to be and act in its favor so as to avoid any rules that could limit its performance and or activity.

Viewed together, the framings to empower are in a better position compared to the ones to resist. The acceptance and commitment of locals to this new way of being served works well and produces the results intended. The empowering strengthening actions come to connect with local communities and drive their recognition as a legitimate new business and as a reasonable and fair service. Uber skyrocketed in five years. Since 2014, the company plugged more than one hundred Brazilian cities into its riding services (Costa, 2019).

The resisting strengthening actions are sharp and determined to inhibit the advance of the competition. Such actions used coercion, injury, and outrage against the new business competition. Taxicabs engagements brought many people to the streets and acted as if they were in a battle that put them into a position of prevalence in media, e.g., as front-page headlines.

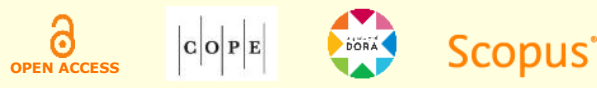


Violent actions, in a way, lead to social rejection. Until then the taxicabs had no intruders, they were in a non-pressure market. Uber emerges and made changes by breaking the conventional way of providing individual transport service.

It is the turn of clients and their right to quality and reasonable prices. They began to have a voice and a choice. More so, Uber challenged locals to question how/why taxicabs and application drivers provide unequal service (price, quality, etc.). In this broader context, the searching for legitimacy approach shows more efficiency at making locals commit to the new potential trend of the SE as (a) a decentralized, equitable and sustainable economy (in the economic system perspective) and as (b) an economic opportunity (in the business market perspective).

It is interesting to observe that the framings to resist make use of sustainability contradictory statements as counter-attack. The economic system perspective, for example, spins the idea of a new economy. However, the path taken by Uber suggests a convenient way to validate capitalist concepts making it more a neoliberal (free market) than a sharing (equitable) economy. The business market perspective shows challenges for both public and private systems. Uber shocked deep-rooted structures in the way it provides individual transport services in an almost untouched industry in the Brazilian context.

Whenever possible, Uber kept itself apart, not engaging with policymakers and public authorities. It questions the truth and even the influence of the ones regulating it and calls for reliable rules in such a way that does not affect the free market (or neoliberalism) view. No doubt, Uber found a societal void between law and society by looking into riding as a service accessible to those out of the traditional industry of taxi drivers offering. Access boosted the market with an innovative income opportunity, but also brought side effects in the establishment of non-legal, black or grey markets, and unfair competition. The individuals (partners, users) take risks, be it concerning the market and the ethical threshold of company actions, or about the activity itself concerning responsibility, i.e., in a case of theft.

Finally, the sustainable-driven perspective gives the impression of being not so appealing from a business point of view. There seems to be no association between sustainable practices and business practices adopted by Uber. However, it does not mean it is not going to take place. Uber is associated with technological disruptions which, in some way, and in a relatively short time, may promote intentional (apart from external impacts) sustainable-driven development. That is the case of the use of clean energy (e.g., electric cars) towards a sustainable-oriented development (Heylighen, 2017). Some positive impacts that generate benefits for the community are particular assistance actions (with partnerships or not), for the donations of food, clothes, blood, etc.; a work environment that reflects diversity; safer trips to reduce drunk driving and more. They also include this general idea of a sustainable mindset for a better way of living (Uber, n.d.). Our findings suggest that SE does have the potential to stimulate a kind of non-reversible sustainable mindset, but the choice depends on the organizations involved in the sharing economy. 


\section{Concluding Remarks}

Our analysis shows a state of affairs in which a kind of mess has thrown the conventional system into new ways of doing business. In our opinion, the SE is part of this process. Despite our findings reframing the SE as an economic opportunity, it also inspires a kind of non-reversible sustainable mind-change. At least, it leads us to the social debate around sustainability and the importance of being critical. We observe that empowering and resisting are not detached from each other; they instead fit into particular ways of doing things. Three coins, each with two sides, in a process mediated by power relations and surrounded by strengthening and vulnerabilities. SE clearly shows a political dimension that justifies further investigation in a still-limited context of theoretical work.

With this objective in mind and contributing to the field, we propose two interrelated theoretical frameworks. In assembling resisting and empowering framings (the two sides of the coin), we find three broader perspectives (the coins) to which both sides direct their efforts. Going further, we recognize the existence of two strengthening actions, each of them stands by the legitimacy of empowering framings or by the commitment with the status quo of resisting framings. This crossfertilization between opposing sides of power relations highlights what is at stake. Each perspective signals the topics that require attention to develop the field. The main issues question whether the new characteristics of the business are or are not capable of changing the contemporary neoliberal economy; whether taking into account the pros and cons, the SE business model is still worthy; and whether SE is sufficiently sustainable-oriented to promote institutional and practices changes.

We highlight two theoretical contributions. The first is the proposition of three broader perspectives through which framings to empower and to resist are connected. Each coin here represents one of these three perspectives: the economic system, the business market, and the sustainable-driven perspectives. The framings, to empower and to resist, appear as the two opposing sides of the same standpoint perspective. The economic system perspective questions the potential of this new model to change the contemporary commercial landscape. The business market highlights issues on the pros and cons of this new SE business model. Finally, sustainabledriven deals with issues linked to sustainable development.

The second theoretical contribution acknowledges some specific movements as strengthening actions. If actions lead to community commitment and support, we label them as searching for legitimacy. On the opposite side, the activities meant to side-step such liability are labeled fighting and calling for the status quo. We also see the contribution to stakeholders as a tool to support SE initiatives. The results should help to monitor what is at stake. Be it by checking the reasoning from a broader perspective or by identifying in what logic the strengthening actions are applied. And, hopefully, tracing less controversial paths towards sustainable development for the SE. 


\section{References}

Agostini, R. (2015, July). Melhor que proibir o Uber é fortalecer os taxistas, diz chefe do CADE. Folha de São Paulo. Retrieved from http://www1.folha.uol.com.br/mercado/2015/07/1654462-melhor-que-proibir-o-uber-efortalecer-os-taxistas-diz-chefe-do-cade.shtml

Aguilhar, L. (2014, September). Estamos em uma campanha política na qual os táxis são a oposição': diz CEO do Uber. O Estado de S. Paulo. Retrieved from http://link.estadao.com.br/noticias/geral,estamos-em-umacampanha-politica-na-qual-os-taxis-sao-a-oposicao-diz-ceo-do-uber, 10000030561

Amora, D. (2014, December). Taxistas se revoltam contra tecnologia. Folha de S. Paulo. Retrieved from http://www1.folha.uol.com.br/mercado/2014/12/1567819-taxistas-se-revoltam-contra-tecnologia.shtml

Apple investe US\$1 bilhão no Didi Chuxing, concorrente chinês do Uber. (2016, May). Retrieved from http://zh.clicrbs.com.br/rs/noticias/noticia/2016/05/apple-investe-us-1-bilhao-no-didi-chuxing-concorrentechines-do-uber-5800531.html

Audiência para discutir regulamentação do Uber é marcada por manifestações. (2016, April). Correio Braziliense. Retrieved from http://www.correiobraziliense.com.br/app/noticia/cidades/2016/04/07/interna_cidadesdf,526299/audiencia -para-discutir-regulamentacao-do-uber-e-marcada-por-manifetac.shtml

Avelino, F. (2009). Empowerment and the challenge of applying transition management to ongoing projects. Policy Sciences, 42(4), 369-390. https://doi.org/10.1007/s11077-009-9102-6

Avelino, F. (2011). Power in transition: Empowering discourses on sustainability transitions. Erasmus University Rotterdam. Retrieved from http://hdl.handle.net/1765/30663

Avelino, F. (2017). Power in sustainability transitions: Analysing power and (dis)empowerment in transformative change towards sustainability. Environmental Policy and Governance, 27(6), 505-520. https://doi.org/10.1002/eet.1777

Avelino, F., \& Rotmans, J. (2009). Power in transition: An interdisciplinary framework to study power in relation to structural change. European Journal of Social Theory, 12(4), 543-569. https://doi.org/10.1177/1368431009349830

Avelino, F., \& Rotmans, J. (2011). A dynamic conceptualization of power for sustainability research. Journal of Cleaner Production, 19(8), 796-804. https://doi.org/10.1016/j.jclepro.2010.11.012

Avital, M., Anderson, M., Nickerson, J., Sundararajan, A., Van Alstyne, M., \& Verhoeven, D. (2014). The collaborative economy: A disruptive innovation or much ado about nothing? International conference on information systems, Auckland, New Zealand, 35. Retrieved from http://aisel.aisnet.org/icis2014/proceedings/Panels/5/

Bardhi, F., \& Eckhardt, G. M. (2012). Access-based consumption: The case of car sharing. Journal of Consumer Research, 39(4), 881-898. https://doi.org/10.1086/666376

Belk, R. (2014). Sharing versus pseudo-sharing in web 2.0. Anthropologist, 18(1), 7-23. https://doi.org/10.1080/09720073.2014.11891518

Benford, R. D., \& Snow, D. A. (2000). Framing processes and social movements: An overview and assessment. Annual Review of Sociology, 26, 611-639. https://doi.org/10.1146/annurev.soc.26.1.611

Benkler, Y. (2006). The wealth of networks: How social production transforms markets and freedom. Retrieved from http://www.benkler.org/Benkler_Wealth_Of_Networks.pdf

Bergamim, G., Jr. (2015, September). Impor limites vai gerar um mercado paralelo, diz gerente-geral do Uber. Folha de S. Paulo. Retrieved from http://m.folha.uol.com.br/cotidiano/2015/09/1687808-impor-limites-vai-gerar-ummercado-paralelo-diz-gerente-geral-do-uber.shtml

Bernardes, A., \& Alves, R. (2015, August). Pressão contra Uber revela poder histórico de taxistas em Brasília. Correio Braziliense. Retrieved from http://www.correiobraziliense.com.br/app/noticia/cidades/2015/08/06/interna_cidadesdf,493526/serie-dereportagens-mostra-o-poder-dos-taxistas-ao-longo-de-40-anos.shtml

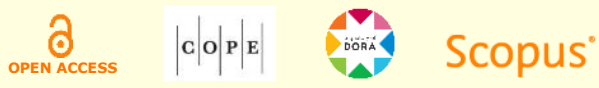


Bohnsack, R., Pinkse, J., \& Kolk, A. (2014). Business models for sustainable technologies: Exploring business model evolution in the case of electric vehicles. Research Policy, 43(2), 284-300. https://doi.org/10.1016/j.respol.2013.10.014

Bonciu, F., \& Bâlgăr, A.C. (2016). Sharing economy as a contributor to sustainable growth: An EU perspective. Romanian Journal of European Affairs, 16(2), 36-45. Retrieved from http://rjea.ier.gov.ro/wpcontent/uploads/articole/RJEA_2016_vol16_no2_art_3.pdf

Botsman, R., \& Rogers, R. (2011). O que é meu é seu: Como o mundo vai mudar o seu (o nosso) mundo. Porto Alegre, Brazil: Bookman.

Boyd, C., \& Kietzmann, J. (2014). Ride on! Mobility business models for the sharing economy. Organization $\mathcal{E}$ Environment, 27(3), 279-296. https://doi.org/10.1177/1086026614546199

Capelas, B. (2014, May). Aplicativo de caronas; Uber pode valer até US\$ 17 bilhões. O Estado de S. Paulo. Retrieved from

http://link.estadao.com.br/noticias/geral,aplicativo-de-caronas-uber-pode-valer-ate-us-17bilhoes, 10000031265

Cazarré, M. (2015, November). Comissão de Legislação Participativa debate regulamentação do aplicativo Uber. Agência Brasil. Retrieved from http://agenciabrasil.ebc.com.br/politica/noticia/2015-11/camara-debateregulamentacao-do-aplicativo-uber

Chaves, J. E. de R., Jr. (2016, April). Motorista do Uber poderá ser considerado empregado no Brasil. Migalhas. Retrieved from http://www.migalhas.com.br/dePeso/16,MI237918,41046Motorista+do+Uber+podera+ser+considerado+empregado+no+Brasil

Cohen, M., \& Sundararajan, A. (2015). Self-regulation and innovation in the peer-to-peer sharing economy. University of Chicago Law Review Online, 82(1), 116-133. Retrieved from https://chicagounbound.uchicago.edu/cgi/viewcontent.cgi?article=1039\&context $=$ uclrev_online

Com as novas opções de transporte, carro e táxi perdem competitividade. (2016, June). Estado de Minas. Retrieved from http://www.em.com.br/app/noticia/economia/2016/06/20/internas_economia,774650/com-as-novasopcoes-de-transporte-carro-e-taxi-perdem-competitividade.shtml

Costa, C. (2019, July 17). Uber completa 5 anos de Brasil com 2,6 bilhões de viagens realizadas. Uber Newsroom. Retrieved August 25, 2019, from https://www.uber.com/pt-BR/newsroom/uber-completa-5-anos-de-brasil-com26-bilhoes-de-viagens-realizadas/

Czarniawska, B. (2010). The uses of narratology in social and policy studies. Critical Policy Studies, 4(1), 58-76. https://doi.org/10.1080/19460171003715002

Decisão sobre regulamentação do Uber deve ficar para o segundo semestre. (2016, June). Retrieved from http://www.correiobraziliense.com.br/app/noticia/cidades/2016/06/28/interna_cidadesdf,538114/decisaosobre-regulamentacao-do-uber-deve-ficar-para-o-segundo-semestr.shtml

De Stefano, V. (2015). The rise of the just-in-time workforce: On-demand work, crowdwork, and labor protection in the gig-economy. Comparative Labor Law $\mathbb{E}$ Policy Journal, 37(3), 471-504. http://dx.doi.org/10.2139/ssrn.2682602

Diógenes, J., \& Thomé, C. (2016, May). Motoristas da Uber formam minifrotas, cobram diárias e exigem parte de lucros. O Estado de S. Paulo. Retrieved from http://sao-paulo.estadao.com.br/noticias/geral,motoristas-da-uberformam-minifrotas--cobram-diarias-e-exigem-parte-de-lucros, 10000049779

Domingos, R. (2016, August). MPF apura denúncia de exploração trabalhista pelo Uber. G1 O Globo. Retrieved from http://g1.globo.com/sao-paulo/noticia/2016/08/associacao-de-motoristas-denuncia-uber-porirregularidades-trabalhistas.html

Donini, A., Forlivesi, M., Rota, A., \& Tullini, P. (2017). Towards collective protections for crowdworkers: Italy, Spain and France in the EU context. Transfer, 23(2), 207-223. https://doi.org/10.1177/1024258916688863

Dowling, R., \& Kent, J. (2015). Practice and public-private partnerships in sustainable transport governance: The case of car sharing in Sydney, Australia. Transport Policy, 40, 58-64. https://doi.org/10.1016/j.tranpol.2015.02.007 
Dreyer, B., Lüdeke-Freund, F., Hamann, R., \& Faccer, K. (2017). Upsides and downsides of the sharing economy: Collaborative consumption business models' stakeholder value impacts and their relationship to context. Technological Forecasting and Social Change, 125, 87-104. https://doi.org/10.1016/j.techfore.2017.03.036

Eckhardt, G. M., \& Bardhi, F. (2015, January 28). The sharing economy isn't about sharing at all. Harvard Business Review, 1-3. Retrieved from https://hbr.org/2015/01/the-sharing-economy-isnt-about-sharing-at-all.

Fabio. (2016, August). Sobre o decreto municipal publicado hoje em Vitória. Uber blog. Retrieved from https://newsroom.uber.com/brazil/sobre-o-decreto-municipal-publicado-hoje-em-vitoria/

Fabo, B., Karanovic, J., \& Dukova, K. (2017). In search of an adequate European policy response to the platform economy. Transfer: European Review of Labour and Research, 23(2), 163-175. https://doi.org/10.1177/1024258916688861

Firnkorn, J., \& Müller, M. (2011). What will be the environmental effects of new free-floating car-sharing systems? The case of Car2go in Ulm. Ecological Economics, 70(8), 1519-1528. https://doi.org/10.1016/j.ecolecon.2011.03.014

Freitas, C. S. de, Petrini, M., \& Silveira, L. M. da. (2016). Desvendando o consumo colaborativo: Uma proposta de tipologia. Congresso Latino-Americano de Varejo, São Paulo, SP, Brazil, 9.

Freitas, R. de C. M., Nélsis, C. M., \& Nunes, L. S. (2012). A crítica marxista ao desenvolvimento (in)sustentável. Revista Katálysis, 15(1), 41-51. https://doi.org/10.1590/S1414-49802012000100004

Fremstad, A. (2017). Does Craigslist reduce waste? Evidence from California and Florida. Ecological Economics, 132 , 135-143. https://doi.org/10.1016/j.ecolecon.2016.10.018

Galdino, R. (2015, July). Especialistas defendem boa convivência com Uber. Hoje em Dia. Retrieved from http://hojeemdia.com.br/horizontes/especialistas-defendem-boa-conviv\%C3\%AAncia-com-uber-1.315656

Geels, F. W. (2004). From sectoral systems of innovation to socio-technical systems: Insights about dynamics and change from sociology and institutional theory. Research Policy, 33(6-7), 897-920. https://doi.org/10.1016/j.respol.2004.01.015

Geels, F. W. (2010). Ontologies, socio-technical transitions (to sustainability), and the multi-level perspective. Research Policy, 39(4), 495-510. https://doi.org/10.1016/j.respol.2010.01.022

Geissinger, A., Laurell, C., Öberg, C., \& Sandström, C. (2019). How sustainable is the sharing economy? On the sustainability connotations of sharing economy platforms. Journal of Cleaner Production, 206, 419-429. https://doi.org/10.1016/j.jclepro.2018.09.196

Gomes, R. C. (2005). Who are the relevant stakeholders to the local government context? Empirical evidences on environmental influences in the decision-making process of English local authorities. Revista de Administração Contemporânea, 1(1), 177-202. https://doi.org/10.1590/S1807-76922004000100004

Gonzaga, Y. (2014, December). Uber acelera o crescimento e o número de polêmicas em que se envolve. Folha de S. Paulo. Retrieved from https://www1.folha.uol.com.br/tec/2014/12/1556168-uber-acelera-o-crescimento-e-onumero-de-polemicas-em-que-se-envolve.shtml

Griffith, D. A., van Esch, P., \& Trittenbach, M. (2018). Investigating the mediating effect of Uber's sexual harassment case on its brand: Does it matter? Joumal of Retailing and Consumer Services, 43, 111-118. https://doi.org/10.1016/j.jretconser.2018.03.007

Hamari, J., Sjöklint, M., \& Ukkonen, A. (2016). The sharing economy: Why people participate in collaborative consumption. Journal of the Association for Information Science and Technology, 67(9), 2047-2059. https://doi.org/10.1002/asi.23552

Heinrichs, H. (2013). Sharing economy: A potential new pathway to sustainability. GAIA: Ecological Perspectives for Science $\mathcal{E}$ Society, 22(4), 228-231. http://dx.doi.org/10.14512/gaia.22.4.5

Heylighen, F. (2017). Towards an intelligent network for matching offer and demand: From the sharing economy to the global brain. Technological Forecasting and Social Change, 114, 74-85. https://doi.org/10.1016/j.techfore.2016.02.004 
Hockerts, K., \& Wüstenhagen, R. (2010). Greening Goliaths versus emerging Davids - Theorizing about the role of incumbents and new entrants in sustainable entrepreneurship. Journal of Business Venturing, 25(5), 481-492. https://doi.org/10.1016/j.jbusvent.2009.07.005

Hofmeister, R. (2016, May 21). O Uber não afetará apenas o taxista. Tribuna da Bahia. Retrieved from http://www.tribunadabahia.com.br/2016/05/21/uber-nao-afetara-apenas-taxista

Hong, S., \& Vicdan, H. (2016). Re-imagining the utopian: Transformation of a sustainable lifestyle in ecovillages. Journal of Business Research, 69(1), 120-136. https://doi.org/10.1016/j.jbusres.2015.07.026

Investimento saudita na Uber causa desconforto. (2016, July). Jornal do Brasil. Retrieved from http://m.jb.com.br/economia/noticias/2016/07/24/wsj-investimento-saudita-na-uber-causa-desconforto/

Konefal, J. (2013). Environmental movements, market-based approaches, and neoliberalization: A case study of the sustainable seafood movement. Organization $\mathcal{E} \quad$ Environment, 26(3), 336-352. https://doi.org/10.1177/1086026612467982

Krush, M. T., Pennington, J. R., Fowler, A. R., \& Mittelstaedt, J. D. (2015). Positive marketing: A new theoretical prototype of sharing in an online community. Joumal of Business Research, 68(12), 2503-2512. https://doi.org/10.1016/j.jbusres.2015.06.037

Langley, A., \& Abdallah, C. (2011). Templates and turns in qualitative studies of strategy and management. In D. Bergh, \& D. Ketchen (Eds.), Building methodological bridges (Research methodology in strategy and management, Vol. 6, pp. 201-235). Bingley, UK: Emerald Group Publishing Limited. https://doi.org/10.1108/S14798387(2011)0000006007

Laurell, C., \& Sandström, C. (2017). The sharing economy in social media: Analyzing tensions between market and non-market logics. Technological Forecasting and Social Change, 125, 58-65. https://doi.org/10.1016/j.techfore.2017.05.038

Malhotra, A., \& Van Alstyne, M. (2014). The dark side of the sharing economy ... and how to lighten it. Communications of the ACM, 57(11), 24-27. https://doi.org/10.1145/2668893

Martin, C. J. (2016). The sharing economy: A pathway to sustainability or a nightmarish form of neoliberal capitalism? Ecological Economics, 121, 149-159. https://doi.org/10.1016/j.ecolecon.2015.11.027

Martin, C. J., Evans, J., \& Karvonen, A. (2018). Smart and sustainable? Five tensions in the visions and practices of the smart-sustainable city in Europe and North America. Technological Forecasting and Social Change, 133, $269-278$. https://doi.org/10.1016/j.techfore.2018.01.005

Martin, C. J., \& Upham, P. (2016). Grassroots social innovation and the mobilisation of values in collaborative consumption: A conceptual model. Journal of Cleaner Production, 134(A), 204-213. https://doi.org/10.1016/j.jclepro.2015.04.062

McKee, D. (2017). Neoliberalism and the legality of peer platform markets. Environmental Innovation and Societal Transitions, 23, 105-113. https://doi.org/10.1016/j.eist.2017.04.001

Michele. (2014, September). Belo Horizonte your secret ubers have landed. Uber Newsroom. Retrieved from https://newsroom.uber.com/brazil/belo-horizonte-your-secret-ubers-have-landed-2/

Ming, C. (2016, August). Metamorfose do trabalho. O Estado de S. Paulo. Retrieved from http://economia.estadao.com.br/noticias/geral,metamorfose-do-trabalho, 10000070737

Moraes, T. (2016, April). Start-ups ganham espaço em cenários de crise econômica. Hoje em Dia. Retrieved from http://hojeemdia.com.br/primeiro-plano/start-ups-ganham-espa\%C3\%A7o-em-cen\%C3\%A1rios-de-criseecon\%C3\%B4mica-1.378253

Morozov, E. (2013, October 14). The "sharing economy" undermines workers' rights. The Financial Times, 11. Retrieved from https://www.ft.com/content/92c3021c-34c2-11e3-8148-00144feab7de

Murillo, D., Buckland, H., \& Val, E. (2017). When the sharing economy becomes neoliberalism on steroids: Unravelling the controversies. Technological Forecasting and Social Change, 125, 66-76. https://doi.org/10.1016/j.techfore.2017.05.024 
Ninio, M. (2015, September). 'Uberização' gera debate na corrida pela Casa Branca. Folha de São Paulo. Retrieved from http://www1.folha.uol.com.br/fsp/mercado/232351-uberizacao-gera-debate-na-corrida-pela-casabranca.shtml

Price Waterhouse. (2015). The sharing economy - Sizing the revenue opportunity. Retrieved February 23, 2016, from http://www.pwc.co.uk/issues/megatrends/collisions/sharingeconomy.html

Ribeiro, M. (2016, May). OAB deve pedir legalização dos serviços de Uber em Fortaleza. Tribuna do Ceará. Retrieved from https://tribunadoceara.com.br/noticias/mobilidadeurbana/oab-deve-pedir-legalizacao-dos-servicos-deuber-em-fortaleza/

Rifkin, J. (2014). The zero-marginal cost society: The internet of things, the collaborative commons and the eclipse of capitalism. New York, NY: Palgrave Macmillan.

Rip, A., \& Kemp, R. (1998). Technological change. In S. Rayner, \& E. L. Malone (Eds.), Human Choice and Climate Change (pp. 327-399). Retrieved from https://pdfs.semanticscholar.org/4739/5c4a2d310598d1e945873ee3787535df2844.pdf

Rodrigues, G. (2016, July.). "É normal motorista sair e voltar”. O Popular. Retrieved from http://www.opopular.com.br/editorias/cidade/\%C3\%A9-normal-motorista-sair-e-voltar-1.1124597

Rodrigues, L. (2016, May). Qual a cara da Uber no Recife? Diário de Pernambuco. Retrieved from http://www.impresso.diariodepernambuco.com.br/app/noticia/cadernos/vidaurbana/2016/05/01/interna_v idaurbana, 143759/a-cara-da-uber-no-recife.shtml

Saiba quanto custa se locomover em Goiânia. (2016, February). Diário da Manhã. Retrieved from: http://www.dm.com.br/economia/2016/02/saiba-quanto-custa-se-locomover-em-goiania.html

Saitto, S., \& Stone, B. (2014, June). Aplicativo de táxi dos EUA já vale US\$17 bi. Bloomberg/O Estado de S. Paulo. Retrieved from http://economia.estadao.com.br/noticias/geral,aplicativo-de-taxi-dos-eua-ja-vale-us-17-bi-imp,1507221

Schor, J. B., \& Attwood-Charles, W. (2017). The "sharing” economy: Labor, inequality, and social connection on for-profit platforms. Sociology Compass, 11(8), e12493. https://doi.org/10.1111/soc4.12493

Schor, J. B., Fitzmaurice, C., Carfagna, L. B., Attwood-Charles, W., \& Dubois Poteat, E. (2016). Paradoxes of openness and distinction in the sharing economy. Poetics, 54, 66-81. https://doi.org/10.1016/j.poetic.2015.11.001

Silva, A. R. L. da, Carrieri, A. de P., \& Souza, E. M. de. (2012). A constructionist approach for the study of strategy as social practice [Special Issue]. Brazilian Administration Review, 9, 1-18. http://dx.doi.org/10.1590/S180776922012000500002

Smith, A., \& Raven, R. (2012). What is protective space? Reconsidering niches in transitions to sustainability. Research Policy, 41(6), 1025-1036. https://doi.org/10.1016/j.respol.2011.12.012

Sorkin, A. R. (2016, July). Uber usa bilhões para 'sufocar' seus rivais. O Estado de S. Paulo. Retrieved from http://link.estadao.com.br/noticias/empresas,uber-usa-bilhoes-para-sufocar-seus-rivais, 10000061892

Sosna, M., Trevinyo-Rodríguez, R. N., \& Velamuri, S. R. (2010). Business model innovation through trial-and-error learning: The naturhouse case. Long Range Planning, 43(2-3), 383-407. https://doi.org/10.1016/j.lrp.2010.02.003

Sprague, R. (2015). Worker (mis) classification in the sharing economy: Square pegs trying to fit in round holes. ABA Journal of Labor \&ु Employment Law, 31(1), 53-76. Retrieved from https://works.bepress.com/robert_sprague/29/

Streitfeld, D. (2014, February). Empresa de transporte trilha caminho tortuoso. Gazeta do Povo. Retrieved from https://www.gazetadopovo.com.br/mundo/new-york-times/empresa-de-transporte-trilha-caminho-tortuosoeo2fex7pa0ci1ns6rzopb83m6/

Tendência teve início na década de 1970. (2015, July). O Estado de S. Paulo. Retrieved from http://economia.estadao.com.br/noticias/geral,tendencia-teve-inicio-na-decada-de-1970-imp-,1726130

Uber. (n.d.). The history of Uber. Retrieved July 14, 2019, from https://www.uber.com/pt-BR/newsroom/História/

Uber. (2016, October 20). \#ficauberpoa [Advertisement]. Zero Hora, 53(18600).

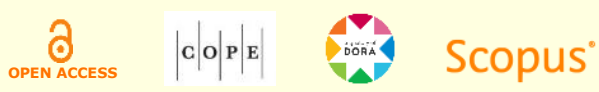


Uber. (2019, May 10). Fatos e dados sobre a Uber. Retrieved from https://www.uber.com/pt-BR/newsroom/fatos-edados-sobre-uber/

Uber começa a aceitar pagamento em dinheiro no Distrito Federal. (2016, August). Correio Braziliense. Retrieved from

http://www.correiobraziliense.com.br/app/noticia/cidades/2016/08/12/interna_cidadesdf,544242/ubercomeca-a-aceitar-pagamento-em-dinheiro-no-distrito-federal.shtml

Uber será tratado como transporte clandestino, diz EPTC. (2015, November). ZH ClicRBS. Retrieved from http://zh.clicrbs.com.br/rs/noticias/noticia/2015/11/uber-sera-tratado-como-transporte-clandestino-diz-eptc4909909.html

Verboven, H., \& Vanherck, L. (2016). The sustainability paradox of the sharing economy. Sustainability Management Forum, 24(4), 303-314. https://doi.org/10.1007/s00550-016-0410-y

WRI Brasil. (2016, March). Inovações disruptivas em prol da mobilidade urbana. Retrieved from http://wricidades.org/noticia/inova\%C3\%A7\%C3\%B5es-disruptivas-em-prol-da-mobilidade-urbana

Zwick, A. (2018). Welcome to the Gig Economy: Neoliberal industrial relations and the case of Uber. GeoJournal, 83(4), 679-691. https://doi.org/10.1007/s10708-017-9793-8

\section{Author contributions}

$1^{\text {st }}$ author: conceptualization (equal), data curation (equal), formal analysis (equal), funding acquisition (equal), investigation (equal), methodology (equal), project administration (equal), resources (equal), software (equal), supervision (equal), validation (equal), visualization (equal), writing-original draft (equal), writing-review and editing (equal).

$2^{\text {nd }}$ author: conceptualization (equal), data curation (equal), formal analysis (equal), funding acquisition (equal), investigation (equal), methodology (equal), project administration (equal), resources (equal), software (equal), supervision (equal), validation (equal), visualization (equal), writing-original draft (equal), writing-review and editing (equal).

\section{Authors}

\section{Gicelda Julia Dal Bó}

Pontifícia Universidade Católica do Rio Grande do Sul, Escola de Negócios

Av. Ipiranga, 6681, Prédio 50, 11 andar, Bairro Partenon, 90619-900, Porto Alegre, RS, Brazil gdalbo@gmail.com

(iD) https://orcid.org/0000-0002-6115-7998

\section{Maira Petrini}

Pontifícia Universidade Católica do Rio Grande do Sul, Escola de Negócios

Av. Ipiranga, 6681, Prédio 50, 11 andar, Bairro Partenon, 90619-900, Porto Alegre, RS, Brazil

maira.petrini@pucrs.br

(iD) https://orcid.org/0000-0002-3914-2589

Peer review is responsible for acknowledging an article's potential contribution to the frontiers of scholarly knowledge on business or public administration. The authors are the ultimate responsible for the consistency of the theoretical references, the accurate report of empirical data, the personal perspectives, and the use of copyrighted material. 